\title{
Current International Legal Issues: Vietnam
}

\author{
Trinh Hai Yen* and Ton Nu Thanh Binh**
}

With the foreign policy of independence, self-reliance, peace, cooperation and development, Vietnam has been actively participating in the international legal system since Doi Moi (Renovation) in 1986. International law plays an important role in protecting sovereignty, territorial integrity, peace, security and cooperation. This article aims to introduce some of the most significant international law issues that Vietnam is currently facing and how they are being applied in practice. They are issues pertaining to the law of the sea, investment and trade law, human rights, and diplomatic protection of citizens abroad.

Vietnam, with $3,444 \mathrm{~km}$ of coastline, is surrounded by the South China Sea to the east, the south and the southwest. The latter is widely known as home to most maritime disputes in the Asia Pacific region, due to its geopolitical location and abundant resources. The South China Sea serves as the sea route for more than half of global trade and the majority of oil imports from the Middle East to China, Japan and South Korea, while providing $12 \%$ of global fish products, which greatly contributes to food security and economic development of China, Vietnam and the Philippines, ${ }^{1}$ as well as non-living resources that are essential for the energy needs of industrializing countries like China. ${ }^{2}$ Situated at the center of South East Asia, Vietnam is a key stakeholder in maritime disputes over the South China Sea. Issues pertaining to the Law of the Sea are therefore a critical concern for Vietnam, not only for the protection of national sovereignty and territorial integrity, but also for the maintenance of peace and

* Faculty of International Law, Diplomatic Academy of Vietnam. The opinions expressed in this article are solely those of the authors. They do not pupport to reflect the opinions or views of any institution they might be affiliated with.

** Teaching Assistant, Faculty of International Law, Diplomatic Academy of Vietnam.

1 Sharif Mustajib, Geopolitical and Strategic Landscape of South China Sea, http://international affairsbd.com/geopolitical-strategic-landscape-south-china-sea/.

2 China Claims Breakthrough in Mining 'Flammable Ice', BBC News (May 19, 2017), http://www. bbc.com/news/world-asia-china-39971667. 
security in the region. This is evidenced in the adoption of Vietnam Law of the Sea in 2012, whose objective is to clarify and reaffirm Vietnam's sovereignty, sovereign rights and jurisdiction in its respective maritime zones, as well as to regulate maritime economic development, the management and protection of the sea and islands. ${ }^{3}$

This part seeks to briefly introduce Vietnam's maritime law enforcement agencies (MLEA), efforts in the negotiation of the Code of Conduct in the South China Sea (COC) and response to the 2016 South China Sea arbitration.

\section{a Vietnam's Use of MLEA}

Since the entry into force of the United Nations Convention on the Law of the Sea (UNCLOS), the newly-created maritime zones have made sea management more challenging. On the one hand, there is the rise of a wide spectrum of maritime threats - from natural disasters to transboundary maritime crimes, such as environmental pollution, IUU fishing, drug trafficking, slavery, armed robbery and piracy, which requires the policing role of coast guards. On the other hand, from Vietnam's perspective, there is China's growing assertiveness to control the whole South China Sea, which calls for response from claimant states to protect their legitimate rights and interests. In this regard, it is beneficial to share the mandate of defence among navies and other MLEA, given the cost-effectiveness and flexibility in maneuver of coast guard vessels.

The new Law on Vietnam Coast Guard (VCG) was adopted in November 2018 and will come into force in July 2019. The Law, which replaces the 2008 Ordinance on VCG, aims to clarify the responsibilities and function of the VCG, giving it more flexibility to operate. Under this Law, the VCG is a core force of Vietnamese MLEA due to its full spectrum of charges in maritime law enforcement in all maritime zones. It has the double role of a military force and a professional "police at sea,"4 being responsible for defending national sovereignty, sovereign rights and jurisdiction, maintaining security, order and safety, preventing and combating crimes and violations of the law, as well as search and rescue activities in accordance with international law. ${ }^{5}$

Unlike other professional forces, the VCG has two rights specialized for military ships: hot pursuit and open fire. The right of hot pursuit is realized outside the territorial sea and safety zones around artificial islands, installations and structures on continental shelf zone, to the high sea for subjects who have committed violations in the internal water, territorial sea, exclusive economic

3 LaW of the Sea of Vietnam, No. 18/2012/QH13, promulgated by the National Assembly on June 21, 2012, art. 1.

4 Law on Vietnam Coast Guard [VCG] arts. 3, 8.

5 VCG art. 8. 
zone or on continental shelf of coastal state. ${ }^{6}$ The right of opening fire can be adopted amid a hot pursuit over vehicles at sea that violate laws and regulations of Vietnam, but only limited to exceptional cases. ${ }^{7}$

The key of success of Vietnamese MLEA lies in the mechanism of division and coordination. The VCG acts as a core force of the MLEA with the other professional forces in satellite, such as the Navy, Vietnamese Fishery Resources Surveillance Force (VFRSF), Vietnam Border Defense Force, the maritime militia and self-defense force. In emergency situations, officers and soldiers of the VCG may mobilize people, vessels and civil engineering means and equipment of other MLEAs. ${ }^{8}$ This mobilization must depend on the actual capabilities of the mobilized persons, vessels or civil engineering means or equipment, which must be returned immediately after the emergency situation ceases to exit. ${ }^{9}$

The effectiveness of coordination among Vietnam's MLEA has been proven in the Haiyang Shiyou-981 oil rig incident..$^{10}$ On May 1, 2014, the HYsY 981 oil rig, escorted by a large fleet of armed vessels, military ships and aircraft, was placed deeply inside Vietnam's exclusive economic zone." In accordance with the uNCLOS, Vietnam demanded China to withdraw the oil rig. In response, China announced its intention to deploy the oil rig until the end of August 2014 as a normal operation in the Chinese claimed water. Vietnam mobilized about 60 vessels of the VCG, VFRSF and militia under the command of the coast guard to prevent this illegal action. Meanwhile, China used more than 130 vessels from China Coast Guard (CCG), civilian fishing and Chinese navy vessels to threaten by ramming or firing water cannons. Throughout the period of over two and a half months, despite the ramming and firing with high-pressure water cannons by the Chinese part, the Vietnamese MLEA remained patient and persistent in demands towards China. Eventually, on July 15th, 2014, the Chinese National

6 U.N. Convention on the Law of the Sea art. 111, opened for signature Dec. 10, 1982, 1833 U.N.T.S. 397 (entered into force Nov. 16, 1994).

7 VCG art. 14.

8 VCG art. 13.

$9 \quad$ Id.

10 Fisheries Surveillance Force, GLOB.Security.org, https://www.globalsecurity.org/ military/world/vietnam/fisheries-surveillance.htm (last visited Mar. 24, 2019).

11 Michael Green et al., Counter-Coercion Series: China-Vietnam Oil Rig Standoff, Asia Mar. TransparenCy Initiative (June 12, 2017), https://amti.csis.org/counter-co-oil-rigstandoff/; Carl Thayer, 4 Reasons China Removed Oil Rig HYSY-981 Sooner Than Planned, The Diplomat (July 22, 2014), https://thediplomat.com/2014/07/4-reasons-chinaremoved-oil-rig-hysy-981-sooner-than-planned/; Tran Sy Vy, Oil Rig HD 981 Incident: From the Angle of the International Law, VIET. L. \& LEGAL F. (Aug. 22, 2014), http://vietnamlawmagazine.vn/oil-rig-hd-981-incident-from-the-angle-of-the-international-law-3588.html. 
Offshore Oil Company (CNOOC) announced the rig's withdrawal a month in advance. $^{12}$

This incident has proven the rightness of Vietnam's approach in coordinating its different maritime law enforcement forces under the unique commandment of the VCG to reach its goal. Facing the Chinese detachment, which is greater in size and weapons, Vietnam MLEA convincingly demonstrated their determination to settle conflicts by peaceful means, adhering to international law, which has avoided a possible military clash between the two countries.

\section{b The Code of Conduct in the South China Sea (coc)}

Participating in the negotiation of the COC is one of Vietnam's priorities in the law of the sea. On October 22, 2018, the 12th Party Central Committee of Vietnam passed Resolution 36/NQ-TW on "Strategy for the sustainable development of Vietnam's marine economy until 2030, with a vision until 2045." The Resolution noted that Vietnam will "actively participate in international and regional forums, especially maritime cooperation activities within ASEAN, coordinating with other countries to fully and effectively implement the Declaration on the Conduct of the South China Sea (DOC) and promoting the signing of the Code of Conduct in the South China Sea (COC)."13

At the 15th ASEAN-China Senior Officials' Meeting on the Implementation of the Declaration on the Conduct of Parties in the South China Sea in Changsha, China, on 27 June 2018, ASEAN Member States and China had agreed on a Single Draft coc Negotiating Text. ${ }^{14}$ However, challenges still lie ahead for the negotiation on COC as Vietnam and China retain their opposing opinions. For Vietnam, the COC should regard many of the actions carried out by China in the South China Sea in recent years as violating international law, including artificial island building, blockades and use of force.$^{15}$ Vietnam also proposes a ban on the establishment of new Air Defence Identification Zones, which

12 Michael Green et al., supra note 11.

13 Về Chiến lược phát triển bền vũng kinh tế biển Việt Nam đến năm 2030, tầm nhin đến năm 2045 [About the Strategy of Sustainable Sea Economic Development in Vietnam to 2030, Vision to Year 2045] Oct. 22, 2018, Resolution No. 36-NQ/TW.

14 Ass'n of Southeast Asian Nations [ASEAN], Joint Communique of the 51 st ASEAN Foreign Ministers'Meeting, I 74 (Aug. 2, 2018), https://asean.org/storage/2017/o8/51st-AMM-JointCommunique-Final.pdf?fbclid=IwAR2Uh69XSda19I8c_grlmyAkiIOjGjxWwobBG -WLCwhJIco5UvtsOIA5YqM.

15 Greg Torode, Tough South China Sea Talks Ahead as Vietnam Seeks to Curb China's Actions, REUTERS (Dec. 31, 2018, 8:10 AM), https://www.reuters.com/article/us-china-southchina sea-asean/tough-south-china-sea-talks-ahead-as-vietnam-seeks-to-curb-chinas -actions-idUSKCNiOToML. 
China unilaterally announced over the East China Sea in $2013 .{ }^{16}$ Most remarkably, Vietnam demands states to clarify their maritime claims in the South China Sea in accordance with international law, an apparently opposing attempt with the China's policy of blurring its claims with the "nine-dash line."17

In 2020, Vietnam will hold the ASEAN Chair, which will be a significant opportunity for Vietnam to promote the COC negotiation, highlighting its guiding role in building an ASEAN community with strong solidarity and enhanced position in the region.

\section{c Vietnam's Response to the 2016 South China Sea Arbitration}

Being one of the claimants in the South China Sea disputes, Vietnam closely followed the South China Sea arbitration and participated as an observer. As soon as the final award was rendered on July 12, 2006, Vietnam announced its endorsement for the judgment and reaffirmed its position on the case, as demonstrated in the Statement of the Ministry of Foreign Affairs, filed to the Tribunal on December $5,2014 \cdot{ }^{18}$ It strongly supported the settlement of disputes on the South China Sea by peaceful means, refraining from the use or threat of use of force, in accordance with international law, maintaining peace, security and stability in the region. ${ }^{19}$ On that occasion Vietnam also restated its sovereignty over the Spratlys and Paracels, sovereignty, sovereign rights and jurisdiction over its respective waters. ${ }^{20}$

The positive response from Vietnam is evidence that it benefited from the decision of the Tribunal. Indeed, the arbitral award agrees with Vietnam's position on several points: (1) the Tribunal has jurisdiction over the requests of the Philippines relating to the interpretation or application of the UNCLOS;21 $(2)$ all claims by China based on the "nine-dash line" are rejected;22 and (3) all the maritime features claimed by China within 200 nautical miles of Mischief Reef or Second Thomas Shoal and the Mischief Reef and Second Thomas Shoal themselves are rocks or low-tide elevations that do not generate any maritime zones of their own. ${ }^{23}$ The award, although binding only upon the Philippines

\footnotetext{
$16 \quad I d$.

17 Id.

18 Nguyễn Hùng, Việt Nam hoan nghênh Tòa Trọng tài đã đưa ra phán quyết cuối cùng [Vietnam Welcomes the Final Arbitration Award], VOV.VN (July 12, 2016, 17:49 pm), https://vov. vn/chinh-tri/viet-nam-hoan-nghenh-toa-trong-tai-da-dua-ra-phan-quyet-cuoi-cung $-529614 . v 0 v$.

$19 \quad I d$.

$20 \quad I d$.

21 The South China Sea Arbitration (Phil. v. China), Case No. 2013-19, Award, ๆ 36 (Perm. Ct. Arb. 2016).

22 Id.

23 Id.
} 
and China in respect of their dispute, ${ }^{24}$ will become an inseparable part of the interpretation and application of the UNCLOS. It will thus be a reliable legal basis for Vietnam and other claimant states in the South China Sea to clarify and substantiate their claims.

Investment and Trade

a Negotiation and Conclusion of Investment and Trade Treaties

In its active participation in international economic relations, Vietnam has recently joined a number of key free trade agreements, such as the EU-Vietnam Investment Protection Agreement (EviPA) (2018), Comprehensive and Progressive Agreement for Trans-Pacific Partnership (CPTPP) (2018, in force for Vietnam on January 14, 2019), EU-Vietnam FTA (EVFTA) (Published text as of August 2018) and Eurasian Economic Union - Viet Nam FTA (2015), as well as bilateral agreements like Macedonia - Viet Nam BIт (2016), Viet Nam - Chile FTA (2015), Viet Nam - Korea FTA (2015).

In addition, Vietnam, as a member of ASEAN, is also a party to several ASEAN+1 FTAS, namely the ASEAN - Australia New Zealand FTA, ASEAN China FTA, ASEAN - India FTA, ASEAN - Japan FTA, ASEAN - Republic of Korea FTA, ASEAN - AEC. Several FTAS are still under negotiation, such as RCEP $(\operatorname{ASEAN}+6)$.

\section{b Disputes}

Vietnam has actively participated as claimant in five disputes under the WTO dispute settlement mechanism and respondent in eight international investment disputes. Throughout these disputes, Vietnam has made successful attempts in protecting its legal rights and interests.

I Investment Disputes

In the 8 investment disputes, Vietnam has won in 3 cases (McKenzie v. Viet Nam, ${ }^{25}$ Dialasie $v$. Viet Nam, ${ }^{26}$ RECOFI $v$. Viet $\mathrm{Nam}^{27}$ ), settled 1 case (Trinh and

$24 \quad I d$. at 937.

25 McKenzie v. Viet Nam (Perm. Ct. Arb. 2013) (applying US-Viet Nam Trade Relations Agreement).

26 Dialasie v. Viet Nam (Perm. Ct. Arb. 2014) (applying France - Viet Nam BIT (1992)).

27 RECOFI v. Viet Nam, Ruling No. 4A_616/2015 (Fed. Sup. Ct. of Switz. 2016) (applying France - Viet Nam BIT (1992)). 
Binh Chau v. Viet Nam ${ }^{28}$ ), 1 case is discontinued (Bryan Cockrell v. Viet Nam ${ }^{29}$ ) and 3 cases are pending (Trinh $v$. Viet Nam, ${ }^{30}$ ConocoPhillips and Perenco $v$. Viet $\mathrm{Nam}^{31}$ Baig v. Viet $\mathrm{Nam}^{32}$ ). Most of these investment arbitrations were brought under bilateral investment treaties with the exceptions of two cases brought under the US-Viet Nam Trade Relations Agreement. They are mainly related to real estate activities, human health and social work activities, accommodation and food service activities, and manufacture of food products.

This success is due to Vietnam's policy in settling investment disputes. When a dispute arises, Vietnam tries to settle with the investor to avoid the costly and lengthy arbitration proceedings. For example, in Trinh and Binh Chau v. Viet Nam, Mr. Trinh Vinh Binh, a Dutch-Vietnamese businessman, alleged that he suffered the confiscation of assets amounting to more than US $\$ 100$ Million. ${ }^{33}$ Mr. Trinh brought claims before the UNCITRAL arbitration, then settled his claim with the Vietnamese government on confidential terms. ${ }^{34}$

In some cases, bifurcation of arbitrations helps host states like Vietnam to minimize costs and resources for the proceedings when they win at the jurisdiction stage. In McKenzie v. Viet $\mathrm{Nam}^{35}$ and RECOFI $v$. Viet Nam, ${ }^{36}$ Vietnam successfully objected to the tribunal's jurisdiction by alleging that the investor did not own an investment in Vietnam under the respective B Iт. ${ }^{37}$ In another

28 Trinh and Binh Chau v. Viet Nam (Stockholm Chamber of Commerce 2007) (applying USViet Nam Trade Relations Agreement).

29 Cockrell v. Viet Nam, PCA Case No. 2015-03 (Perm. Ct. Arb. 2014) (applying US-Viet Nam Trade Relations Agreement).

30 Trinh v. Viet Nam (ICC Int'l Ct. Arb. 2014) (applying Netherlands - Viet Nam BIT (1994)).

31 ConocoPhillips and Perenco v. Viet Nam (2017) (applying United Kingdom - Viet Nam BIT (2002)).

32 Baig v. Viet Nam, ICSID Case No. ARB(AF)/18/2 (2018) (applying Republic of Korea - Viet Nam BIT (1993)).

33 INVEST-SD: Investment Law and Policy News Bulletin, International Institute for Sustainable Development (May 27, 2005), https://www.iisd.org/pdf/2005/invest ment_investsd_may27_2005.pdf.

34 Investment Treaty News, International Institute for Sustainable DevelopMENT (Mar. 27, 2007), https://www.iisd.org/pdf/2007/itn_mar27_2007.pdf.

35 McKenzie v. Viet Nam (Perm. Ct. Arb. 2013).

36 RECOFI v. Viet Nam, Judgment of Sept. 20, 2016, Ruling No. 4A_616/2015 (Fed. Sup. Ct. of Switz.).

37 Thông cáo báo chí của Bộ Tư pháp về vụ kiện của ông Michael McKenzie (công dân Hoa Kỳ) đối với Chính phủ Việt Nam liên quan đến dự án xây dụng khu du lịch nghi duiỡng tại huyện Bắc Binh, tỉnh Bình [Ministry of Justice Press Release on Michael McKenzie's (US citizen) Lawsuit Against the Government of Vietnam Regarding a Project to Build a Resort in Bac Binh District, Binh Dinh], Viet. Ministry of Just. (Mar. 4, 2014), http://www.moj.gov. vn/qt/thongtinbaochi/Pages/thong-cao-bao-chi-ve-cac-su-kien.aspx?ItemID=20. 
case, DialAsie v. Viet Nam, ${ }^{38}$ all the claims by the investor were dismissed since no Vietnamese government agency has violated the France-Vietnam BIт, Vietnamese law or committed any misconduct. ${ }^{39}$

II

Trade Disputes

Since becoming a member of the WTO on 11 January 2007, Vietnam has actively used the dispute settlement mechanism of this Organization to protect its benefits under the wTO rule. Vietnam initiated five cases involving trade remedies against Vietnam's trade in goods. In two cases, DS429 - United States Anti-Dumping Measures on Certain Shrimp from Viet Nam and DS404 - United States - Anti-dumping Measures on Certain Shrimp from Viet Nam, the Wто Dispute Settlement Body ruled that the United States had to change its antidumping measures so as to be consistent with the WTO rules, ensuring benefits of Vietnam enterprises. Vietnam filed a complaint about the safeguard measure applied by Indonesia against imports in 2015 (Indonesia - Iron or Steel Products from Viet Nam) and two complaints in 2018 about measures of the United States imposed on Vietnamese fish fillets and pangasius seafood products (DS536: United States - Anti-Dumping Measures on Fish Fillets from Viet Nam and DS540: United States - Certain Measures Concerning Pangasius Seafood Products from Viet Nam).

Vietnam's claims in DS429 and DS404 focus on two main issues: (i) the "zeroing methodology" in the calculation of dumping margins and (ii) the application of non-market economy ( $\mathrm{NME}$ )-wide entity rates in administrative reviews. ${ }^{40}$

The US's adoption of the "zeroing methodology" to calculate dumping margins has been decided as violating the Anti-dumping Agreement (ADA) and GATT in various prior WTO Appellate Body rulings; ${ }^{41}$ therefore, Vietnam did not face any difficulty in requesting the similar finding. Regarding the application

38 Dialasie v. Viet Nam (Perm. Ct. Arb. 2014).

39 Võ Phương-Sơn Bách, Toà án La Haye phán quyết Chính phủ Việt Nam thắng kiện vụ DialAsie [La Haye Court Ruled That the Vietnamese Government Won the DialAsie Case], VIETNAM+ (Dec. 31, 2014), https://www.vietnamplus.vn/toa-an-la-haye-phan-quyet-chinhphu-viet-nam-thang-kien-vu-dialasie/299733.vnp.

40 US - Shrimp (Viet Nam) (DS404), WTO Dispute Settlement: One-Page Case SumMARIES, https://www.wto.org/english/tratop_e/dispu_e/cases_e/1pagesum_e/ds404sum _e.pdf;US-ShrimpiI (VietNam) (DS429), WTO Dispute Settlement:One-Page CaSe Summaries, https://www.wto.org/english/tratop_e/dispu_e/cases_e/1pagesum_e/ds4 29sum_e.pdf.

US - Shrimp II (Viet Nam) (DS429), supra note 40. 
of NME-wide entity rates by the US in DS429, the Panel found this practice to be inconsistent with Arts. 6.10, 9.2 and 9.4 of the ADA since it "presumes that all producers/exporters in a non-market economy ( $\mathrm{NME}$ ) country belong to a single, NME-wide entity and assigns a single rate" to that entity ${ }^{42}$ In this case, Vietnam has successfully invoked paragraph 255(a) of the Vietnam Accession Working Party Report to argue that "the only special rule committed to by Vietnam concerns the substitution of surrogate values for actual values in calculating normal value." 43 Thus "the USDOC has no legal basis for applying the presumption of state ownership and control that underpins the NME-wide entity practice. ${ }^{\prime 4}$ Vietnam's argument also relied on EC - Fasteners (China) ${ }^{45}$ in which the Appellate Body explained that "an authority may not assume affiliation among several supplier." 46

The DS429 case demonstrated an important issue faced by Vietnam relating to international trade law: the recognition of Vietnam as a market economy. In the wто framework, Vietnam and China are considered non-market economies. Consequently, when determining price comparability under Article vi of the GATT 1994 and the ADA concerning products from these two countries, the importing WTO Member may use prices or costs of a third country instead of prices or costs of Vietnam or China. ${ }^{47}$ As a result, the anti-dumping duties imposed upon products from Vietnam and China are usually much higher than those from market economies.

Recently, China has been engaged in debate with the EU over its market economy status. Paragraph 15 (d) of Protocol on the Accession of China provides that "[o]nce China has established, under the national law of the importing WTо Member, that it is a market economy, the provisions of subparagraph (a) shall be terminated ... [I]n any event, the provisions of subparagraph (a)(ii) shall expire 15 years after the date of accession." Accordingly, China argued that it shall automatically be recognized as a market economy from December 11,

42 Appellate Body Report, United States - Anti-Dumping Measures on Certain Shrimp from Viet Nam, ๆ 1.5.c, WTO Doc. WT/DS429/AB/R (adopted Apr. 7, 2015).

Panel Report Addendum, United States - Anti-Dumping Measures on Certain Shrimp from Viet Nam, at B-15, WTO Doc. WT/DS429/R/Add.1 (adopted Nov. 17, 2014) [hereinafter Panel Report Addendum].

44 Id. at B-5.

45 Id.

$46 \quad I d$.

47 Report of the Working Party on the Accession of Viet Nam, Accession of Vietnam, \ 255, WTO Doc. WT/ACC/VNM/48 (Oct. 27, 2006); Decision, Accession of the People's Republic of China, ๆ 15(a), WTO Doc. WT/L/432 (Nov. 10, 2001). 
2016. Right after this day, China lodged a wTo complaint against the EU $\left(\mathrm{DS}_{516}\right)$ and that panel is ongoing. ${ }^{48}$

The Report of the Working Party on the Accession of Vietnam has a similar provision with paragraph 15 (d) of the China's counterpart, "the provisions of subparagraph (a)(ii) shall expire on 31 December 2018." It is recommended that Vietnam should follow the dispute between China and the EU on this issue.

To gain experience in the WTO dispute settlement mechanism, Vietnam has also participated in 33 disputes as third party at consultation, panel and appellate body stages. Some disputes, such as DS422 relating to imported shrimp to the United States or DS402, DS464, DS471 relating to calculation method of the US in anti-dumping investigations and DS49o relating to safeguard measures of Indonesia on imported steels from Taiwan, are similar to the claims Vietnam has brought against other members. Nonetheless, Vietnam rarely made third-party submissions to express its views on the disputed issues. Its contribution to negotiations on amending the Dispute Settlement Understanding is also limited. Vietnam's full participation in the meetings of the Dispute Settlement Body focuses on advocating for its claims in cases brought before the WTо. This is a priority in Vietnam's international integration policy, as stated in the Comprehensive Strategy on International Integration to 2020 with a vision to 2030 .

\section{4}

\section{Human Rights}

In December 2018, Vietnam released its third-cycle UPR national report, ${ }^{49}$ which provided a comprehensive review of the promotion and protection of human rights in Vietnam over the course of 5 years. According to the report, by October 2018, Vietnam has implemented 175 recommendations $(96.2 \%)$ by the UN Human Rights Council's (UNHRC) second-cycle UPR which it accepted in June 2014. ${ }^{50}$

48 Request for Consultations by China, European Union - Measures Related to Price Comparison Methodologies, WTO Doc. WT/DS516/1 (Dec. 15, 2016), https://www.wto.org/ english/tratop_e/dispu_e/cases_e/ds516_e.htm.

49 Vietnam's Third-Cycle UPR National Report Released, Viet. L. \& Legal F. (Apr. 12, 2018), http://vietnamlawmagazine.vn/vietnams-third-cycle-upr-national-report-released-6487 .html.

50 National Report Submitted in Accordance with 95 of the Annex to Human Rights Council Resolution 16/21 - Viet Nam, Working Group on the Universal Periodic Review on Its Thirty-Second Session, UN Doc. A/HRC/WG.6/32/VNM/1 (Nov. 14, 2018). 
A remarkable achievement of Vietnam in the law of human rights is the participation in most of the key conventions on basic human rights, such as the International Covenant on Civil and Political Rights (ICCPR), International Covenant on Economic, Social and Cultural Rights (ICESCR), Convention on the Elimination of All Forms of Discrimination Against Women (CEDAW), International Convention on the Elimination of All Forms of Racial Discrimination (CERD), Convention on the Rights of the Child (CRC), Optional Protocol to the Convention on the Rights of the Child on the involvement of children in armed conflict, Optional Protocol to the Convention on the Rights of the Child on the sale of children child prostitution and child pornography, Convention on the Rights of Persons with Disabilities (CRPD), Convention against Torture and Other Cruel Inhuman or Degrading Treatment or Punishment (CAT). In addition, Vietnam has also participated in many international conventions on human rights and international humanitarian law, including the Geneva Conventions, Convention on the Prevention and Punishment of Genocide, Convention Statutory Limitations to War Crimes, United Nations Convention Against Transnational Organized Crime.

In terms of national law, between 2014 and 2018, Vietnam has amended, revised and promulgated 96 new laws and ordinances related to human rights. Many important laws were adopted, relating to the People's Procuracy, People's Court, new criminal law with less stringent penalties, right of transgenders, treatment of prisoners and detainees, freedom of speech and expression, freedom of religion, children rights, the reduction of administrative procedures, the use of weapons and explosives and cybersecurity. ${ }^{51}$

\section{a}

Protection of Persons with Disabilities

After signing the Convention on the Rights of Persons with Disabilities in 2007, Vietnam has actively promoted the implementation of the Convention in all areas. First, the adoption of the Law on Persons with Disabilities in 2010 shows Vietnam's strong commitment in ensuring rights of the disabled. This is the first Vietnamese law that expressly recognizes the rights of the disabled in their access to basic necessities and social integration. Many legal instruments were then adopted to establish a stable legal framework for the persons with disabilities, serving as the foundation for Vietnam's ratification of the Convention on the Rights of Persons with Disabilities in 2014. They are ordinances and decisions on the protection of and support for people with mental disorders, orphan abandoned children, or children wth HIV/AIDS. In drafting these legal instruments, the disabled are consulted and encouraged to give direct opinions. 
Besides the development of a legal framework, Vietnam established the National Committee for Persons with Disabilities in 2015, with the function of assisting the Prime Minister in directing and facilitating the coordination among ministries, agencies in works related to the disabled. In addition, 63 legal aid centers are established throughout Vietnam to serve the right of accessing to law of the disabled.

\section{b Prevention of Torture}

Vietnam ratified the Convention against Torture and Other Cruel, Inhuman or Degrading Treatment or Punishment on 28 November 2014. On 7 March 2015, it entered into force for the country. Once Vietnam became a member of the Convention, it had to report on a periodic basis of the implementation of the convention within one year of ratification and then every four years. Accordingly, Vietnam had its first national report on the implementation of the Convention against Torture approved by the Prime Minister on 28 April 2017, before being delivered to the UN Committee Against Torture in Geneva, Switzerland.

The report introduces the efforts and results in the implementation of Vietnam's legislative, executive and judicial measures to prevent and punish acts related to torture and other cruel, inhumane or degrading treatment or punishment. It listed a number of cases related to torture and the use of inhumane treatment which have been investigated and prosecuted recently in Vietnam. The report also identifies shortcomings and challenges that Vietnam faces while implementing the convention and provides plans for effective implementation.

In the implementation of the Convention against Torture, the Prime Minister issued Decision No.65/QD-TTg approving the scheme on propagation of officials, public officers and people about the Convention against Torture and Vietnamese law on the prevention and control of torture. An action plan for implementing the Convention against Torture was also approved by the Supreme People's Procuracy of Vietnam to raise the awareness of public officers about their responsibilities.

\section{Diplomatic Protection of Citizens Abroad}

Vietnam has actively protected the legitimate rights and interests of its citizens abroad. Over the last few years, there occurred many incidents where Vietnamese fishermen entered the exclusive economic zone of other countries in the South China Sea to fish and violated these countries' laws and regulations, despite the Vietnamese government's attempts to prevent. In response, the 
maritime law enforcement forces of other countries have employed tough measures against Vietnamese fishermen, such as the confiscation of fishing vessels, detention of violating fishermen and even use of force. One notable incident happened on 23 September 2017, where two Vietnamese fishermen were killed while 5 others were arrested by the Philippine Navy for illegal fishing inside the Philippine exclusive economic zone. ${ }^{2}$ According to a report by the Philippine police, the Vietnamese boat was spotted in the Bolinao sea, within the Philippines's exclusive economic zone. A navy boat with Bolinao police and coast guard personnel aboard approached and fired warning shots, yet the vessel disregarded and tried to escape, prompting a chase. The boats then collided, the Vietnamese boat stopped after several minutes. The Philippine police boarded and found two dead bodies on the deck. ${ }^{53}$

A legal question arises from the incident: whether the shooting of Vietnamese fishermen by the Philippine Navy was lawful? A Philippine lawyer argued that "[ $\mathrm{t}]$ he Philippines has the sole and exclusive jurisdiction to do so under established international law," therefore "[a]ny foreign vessel that is found fishing in the (EEZ) is considered to be committing the crime of poaching," violating the Philippine Fisheries Code of $1998 .^{54}$

However, even if there has been a violation, the shooting and arresting of Vietnamese fishermen could not be enforced in the EEz where the Philippines only has sovereign rights for exploring, exploiting, conserving and managing the natural resources but not sovereignty. Moreover, under international law, the use of force in the course of maritime law enforcement operations is limited to exceptional cases. As the International Tribunal for the Law of the Sea (ITLOS) Tribunal stated in $M / V$ "SAIGA" case: "Although the [UNCLOS] does not contain express provisions on the use of force in the arrest of ships, international law, which is applicable by virtue of article 293 of the Convention, requires that the use of force must be avoided as far as possible and, where force is unavoidable, it must not go beyond what is reasonable and necessary in the circumstances." 55

52 Carmela Fonbuena, 2 Vietnamese Fishermen Killed in West PH Sea Incident, RAPP LE R (Sept. 24, 2017, 5:45 PM), https://www.rappler.com/nation/183206-vietnamese-fishermen-killedwest-philippine-sea-south-china-sea; Felipe Villamor, Philippines Promises Vietnam a Full Investigation into Fishermen's Deaths, N.Y. Times (Sept. 25, 2017), https://www.nytimes .com/2017/og/25/world/asia/philippines-vietnamese-fishermen.html.

53 Villamor, supra note 52.

54 Arianne Christian Tapao \& Ellen T. Tordesillas, Probe Finds PH Navy at Fault in Death of 2 Vietnamese Fishermen, Source Says, ABS-CBN News (Sept. 30, 2017, 04:09 AM), https:// news.abs-cbn.com/focus/og/30/17/probe-finds-ph-navy-at-fault-in-death-of-2-viet namese-fishermen-source-says.

M/V Saiga (No. 2) (St. Vincent v. Guinea), Case No. 2, Judgment of July 1, 1999, ITLOS Rep. $10,61-2$, ๆ 155 . 
Relying on this principle, Vietnam has raised objections to the Philippines in many occasions. At the request of Vietnamese Deputy Prime Minister and Foreign Minister H.E. Pham Binh Minh, Embassy of Vietnam at the Philippines and Vietnam Ministry of Foreign Affairs' (MOFA) Consular Department in Hanoi, the Philippines has promptly conducted an investigation, sent off the five arrested Vietnamese fishermen, made apologies and promised compensation for the deaths of the two fishermen. ${ }^{56}$

\section{$6 \quad$ Conclusion}

Being a responsible member of the international community, Vietnam uses international law not only for national interests but also for the maintenance of peace and security in the region and the world, contributing to the sustainable development for all. Vietnam's experience with international law is good evidence of how a small and developing country can both rely on and actively contribute to the development of international law in realizing its foreign policies.

56 Fonbuena, supra note 52; Pia Ranada, 'Sorry' Duterte Sends Off Vietnamese Fishermen Shot at by PH Navy, RAPPLER (Nov. 29, 2017, 10:20 PM), https://www.rappler.com/nation/ 189931-philippines-duterte-sorry-send-off-vietnamese-fishermen-navy. 